\title{
Literature Review on the Impression Management in Corporate Information Disclosure
}

\author{
Juling Wang \\ Jinan University, Guangzhou, China \\ Email: 353914220@qq.com
}

Received 16 May 2016; accepted 12 June 2016; published 15 June 2016

Copyright (C) 2016 by author and Scientific Research Publishing Inc. This work is licensed under the Creative Commons Attribution International License (CC BY). http://creativecommons.org/licenses/by/4.0/ c) (i) Open Access

\begin{abstract}
The presentation of corporate disclosure may be explained by impression management. Previous studies find the existence of impression management in the corporate information disclosure including the financial information disclosure and the non-financial information disclosure. This paper is going to make a complete literature review on these studies related to impression management.
\end{abstract}

Keywords

Impression Management, Financial Disclosure, Non-Financial Disclosure

\section{Introduction}

The concept of impression management has its origin in the social psychology and was originally focused on behavior of individuals. It was first introduced by Goffman in 1959. While, recent years, more and more researches had done to investigate the impression management in the corporate information. Impression management can be viewed as a technique that individuals and organizations adopt as an attempt to control the impression that individuals or organizations [1]-[3]. There have been lots of empirical studies which focus on the relationship between the corporate information disclosure and the impression management. These researches try to find out the impression management applied in not only the corporate financial information release [4]-[9] but also the corporate non-financial information release [10] [11]. The existing studies focus on the motivation and effect of impression management in information release especially in the annual reports. The impression management has been applied to explain the reactions of firms facing legitimacy threats [12] and to account for directors' self-serving way of explaining changes in firms' performance in the annual reports [4] [9]. Prior re- 
searches on the effectiveness of impression management focus on the influence of impression on the stock price [9]. Additionally, some experimental methods are used to investigate the effect of impression management on the investors' and managers' prediction and desiccation making [13] [14].

What's more, empirical research also investigates in which way that the companies using impression management in their information release. They may apply impression management technics in the narratives and use graphs to translate their information. Research on the nature of narrative reporting has focused on impression management as an explanation for the style and content of narrative reports [12] [15]-[18]. Studies also reveal that the companies use the impression management technics to offset the potential for adverse selection caused by lack of disclosure [19] [20] particularly where the market is aware of the existence of bad news [21]. When disclosure information, managers tend to emphasize on the good news, they exhibit a self-serving bias in their selection of firm performance items to disclose and their disclosure includes more positive than negative keywords [22] [23].

Corporate information is crucial to the investors, governments as well as the publics. It is because of the significant of the corporate information and the impression management technics in corporate information release. This paper will solve several problems. Firstly, this paper is going to make a review on previous studies in impression management related to corporate information release. We want to give the researchers a general idea about impression management studies in corporate information release and draw brief comments on previous studies. Secondly, this paper wants to give appropriate suggestions to the corporate stakeholders such as the firms, investors and the regulators in order to let them fully understand the corporate information disclosure.

\section{Impression Management}

Impression management originates from social psychology, which focused on behavior of individuals mainly. Goffman first introduced the concept of impression management as "The Presentation of Self in Everyday Life", suggesting that individuals have the objective to achieve congruence between their image and the image that is necessary for the desired goals [1]. While there are still some other authors have different definitions on impression management. Schlenker defined it as the conscious or unconscious attempt to control images that are projected in real or imagined social interactions [24]. Tedeschi and Riess thought that impression management consists of any behavior by a person that has the purpose of controlling or manipulating the attributions and impression formed of that person by others [25]. Although above authors have different descriptions on impression management, their definitions all involve controlling or changing the perception that others have of the person. Jones \& Pittman think impression management as those features of behavior affected by power augmentation motives designed to elicit or shape others' attributions of the actor's dispositions. [26] Leary \&Kowalski define the impression management that the process by which individuals attempt to control the impression others form of them [2]. Research on impression management is in origin targeted at the individual, however it has frequently been conducted in the organizational setting [27]-[31]. This is argued by the assumption that organizations also attempt to control the perception that people have of the organization. As this study is focused on impression management by organizations the term organization will be used, instead of the individual, when impression management is described. Leary and Kowalski (1990) distinguish two processes involving impression management: impression motivation and impression construction. Impression motivation is the condition under which organizations are motivated to influence its public impression. These authors suggest a number of important factors of the motivation namely: the goal-relevance of impression, i.e. how important it is what others think of the person in order to achieve a goal; the value of the desired goal; and the gap between the desired impression and the current impression. Impression construction is the process of determining the impression that an organization wants to provide and the manner in which they attempt to achieve this impression. They suggest a number of variables that determine the construction of impression, namely the way the organizations sees itself, the way the organizations think they are seen by others, the impression an organization wants to give and the role constraints which tell organizations the expectations that society has. With these suggestions Leary and Kowalski argue that impression management is a rational process in which an organization analyses the differences between the current situation and desired status and then decides to use impression management to fill the gap [2].

Through the review of the above literatures, we can see that the impression management gained lots of attentions and many scholars made their own understanding about the impression management. There is no standard definition on the impression management. Generally speaking, we can know that the impression management is 
a process or a tool to help companies fill the gap between the real situation and the desired status. Researches are also find out the impression management technique used in the corporate and try to reveal the motivation and the effectiveness of impression management on the corporate information release. They discuss why the companies want to do impression management in their information disclosure? What is the effect of the impression management on the corporate? These studies solve these questions and make us know deep bout the impression management in the corporate field.

\section{Impression Management in Financial Information Disclosure}

As impression management has been widely applied in various disciplines like organizational behavior, sociology, politics and science, it also used in the accounting field [32]-[35]. In the accounting field, impression management has been mainly researched in the behavior that enterprise managers manipulate firm or control the description of language information in financial report to bring good corporate image to public.

Prior studies suggest that managers apply self-attributing as one of impression management way in their information disclosure. Weiner noticed that people prefer to attribute success to their own ability and attribute failure to external factors [36]. Referring to financial narratives and reports, managers can use specific techniques in an attempt to influence third party impressions. For example, they may select to disclosure the most favorable information from within the whole range of available data. In this way, manager can discuss the most favorable change in performance [37] [38]. Sun in year 2005 empirically examining the self-severing attribution by selecting the observations from China listed companies which performance the best (31 observations) and performance the worst (39 observations) in 2002, showed that companies are likely to attribute better performance to their own abilities while the negative performance to market factors and external environment [39]. Later, Sun et al., took the "SARS epidemic" as background and found that the self-severing behavior will be more obvious when emergence happens [40].

Then, there are researches on the intelligibility and readability of the disclosure information. Adelberg presents that there exists some explanatory bias when managers state non-standard information, by examining the intelligibility of statement notes, MD\&A and auditor reports [41]. Subramanian et al., studied the readability of 60 speeches of board in annual reports of American companies in 1988; found that there are significant differences in readability between companies with good performance and companies with bad performance. The speeches of board with good performance company's report is better to understand [42].

Financial reports as one of the most important ways of information disclosure drive lots of scholars' attentions. This stream of academic research is dedicated to study the impression management in financial reports. Scholars find some tables and pictures can be used in impression management to weaken the effect of bad information on users or strengthen the effect of good information. McKinstry found the company of Burton has conveyed company's image to public through the annual reports with pictures and designs during 1930 to 1994 [43].

Beattie \& Jones shows that over $80 \%$ of the top largest listed in U.K and over $92 \%$ greatest listed companies in US use graphs in their financial release. These graphs are eye-catching. What's more they are been viewed as part of the impression management methodology [44]. Steinbar suggests that, comparing with company with net margin increased, the company with net margin decreased is inclined to use the charts which are designed against the design rules in its annual reports [45]. Sun points out that in practice, companies continuously using integrated impression management strategies such as managing report's content, the narrative, front, color, picture and graph etc. to make indirect influence on investors' psychological feelings [46].

By reviewing these articles, we can tell that the previous studies investigate the impression management in financial information disclosure from different aspects. They find that the self-attributing can be one of the reasons that why managers using impression management techniques. Besides, they also exam the intelligibility and readability of the disclosure information. They find that companies using different narratives and graphs to influence the readability of the information they provided to the stakeholders. All these research from different perspectives verify the existence of impression management in the financial information release.

\section{Impression Management in Non-Financial Information Disclosure}

Non-financial information disclosure belongs to another aspect of corporate information disclosure field. Researches has found that impression management methodology is applied in the non-financial information disclosure. 
Actually, some studies have investigated the effective of impression management in the non-financial information reports. Studies focus on the influence of impression on the stock price. Further, some experimental methods are used to investigate the effect of impression management on the investors' prediction and desiccation making. Staw et al., examine the reasons given by CEOs to explain their firms' performance in annual stockholder reports and find out that the higher self-severing attribution tendency in the CEO's report, the stock price for the company will change positively. This result has no difference in stable firms as well as the unstable firms [9].

Cesario et al., suggest when a message recipient "feels right" from regulatory fit, this subjective experience transfers to the persuasion context and serve as information for relevant evaluations, including perceived message persuasiveness and options of the topic. That is to say, the better message recipients feel, the more they will agree on the message. Firms disclose more quantitative information in their CSR reports may bring two kinds of impression to readers; one kind is that firms attach importance to social responsibility practice that takes more inputs, and firms spend more time searching statistic data used to launch CSR reports, not just meeting the demands of regulators or stakeholders. The other kind is that firms are more sincere and do not confuse information by disclosing more qualitative description [47]

Rämö suggested pictures can enhance the comprehension of reports, especially CSR reports. When pictures and printed words are presented together, it is the picture which readily elicits the first response, because pictures impact the viewer directly without the need for translation within mind. Furthermore, Rämö also thinks reports with incongruent visuals are likely to be distracting and the readers will be able to recall fewer points from the message. Based on above opinions, pictures not only can convey information, but also can make readers focus on some certain information [48]. Breitbarth and Harris argued that visual communication is as important as words and numbers in companies’ non-financial performance to carry information [49]. Cho et al., investigates the language of US corporate environmental disclosure and suggests that there are self-serving biases present in the language and verbal tone used in corporations' environmental disclosures. They use language and verbal tone for managing take holder impressions [10].

From now on we can see that there has been lots of researches about impression management done related to the non-financial information disclosure. Due to the characteristic of non-financial information, scholars find the influence of impression management on the stakeholders. They also find the way how they using impression management in non-financial information disclosure. By reviewing these studies, we can know that when company perform good, they prefer using more quantitative information to gain a good evaluation from the readers. Besides, graphs is another method used by companies to making impression management in their information disclosure.

\section{Conclusions and Suggestions}

Our study makes a literature reviews on the impression management in the corporate disclosure. This paper makes a review form the two aspects: Impression management in the financial information disclosure and impression management in the non-financial information aspect. We find that the previous studies based on the psychology theory and using the self-severing attribution to discuss the corporate behaviors on impression management. Academic research investigates the reasons of why companies doing impression management in information disclosure. What's more, they find that managers apply impression management through the languages they used in narratives and the graphs they used in information release. They also find that the impression management in the corporate information release deed has impact on the readers' psychology. The impression management in the corporate information disclosure has impact on the investors' evaluation on the corporate performance and also has effect on the corporate stock price. All these studies have showed that the impression management gains more and more attentions from both the scholars and the stakeholders.

Furthermore, there are several suggestions for the stakeholders. Due to the significance of the financial information, thus, the investors should be more cautions on the corporate financial information release. They should pay attention to the language or the words that the managers used in order to make right investment decisions. As for regulator, they should make more specific regulations or guidelines on the non-financial information disclosure such as more detailed regulations on the corporate social responsibility reports. As for the firm itself, firm should apply accurate information and add more quantitative information to enhance quality and readability of reports. Thus, the stakeholders can draw an accurate evaluation on the corporation's performance. 


\section{Limitations}

Based on the previous studies which investigate the impression management in corporate information disclosure, we start our research on reviewing these studies in order to draw a general idea about impression management on corporate information disclosure. Although we make literature review on the current researches and make our suggestions, some limitations exist: firstly, we only review the impression management related to the corporate information disclosure and may have some omits related to other aspect of corporate behaviors. Secondly, we review the impression management on corporate information release which has published on the website that we can see. Due to the accessibility, there may be some articles we did not include in this paper. Third, Impression management is a broad concept and the impression management mechanism is sophisticated as well, so there is more space for scholars to investigate.

\section{Reference}

[1] Goffman, E. (1959) The Presentation of Self in Everyday Life. Doubleday, New York.

[2] Leary, M.R. and Kowalski, R.M. (1990) Impression Management: A Literature Review and Two Component Model. Psychological Bulletin, 107, 34-47. http://dx.doi.org/10.1037/0033-2909.107.1.34

[3] Merkl-Davies, D.M., Brennan, N.M. and Mcleay, S.J. (2011) Impression Management and Retrospective Sense-Making in Corporate Narratives: A Social Psychology Perspective. Accounting Auditing \& Accountability Journal, 24, 315-344. http://dx.doi.org/10.1108/09513571111124036

[4] Aerts, W. (1994) On the Use of Accounting Logic as an Explanatory Category in Narrative Accounting Disclosures. Accounting Organizations \& Society, 19, 337-353. http://dx.doi.org/10.1016/0361-3682(94)90001-9

[5] Aerts, W. (2005) Picking up the Pieces: Impression Management in the Retrospective Attributional Framing of Accounting Outcomes. Accounting Organizations \& Society, 30, 493-517. http://dx.doi.org/10.1016/j.aos.2004.07.001

[6] Bettman, J.R. and Weitz, B.A. (1983) Attributions in the Board Room: Causal Reasoning in Corporate Annual Reports. Administrative Science Quarterly, 28, 165-183. http://dx.doi.org/10.2307/2392616

[7] Clapham, S.E. and Schweenk, C.R. (1991) Self-Serving Attributions, Managerial Cognition, and Company Performance. Strategic Management Journal, 12, 219-229. http://dx.doi.org/10.1002/smj.4250120305

[8] Salancik, G.R. and Meindl, J.R. (2010) Corporate Attributions as Strategic Illusions of Management Control. Administrative Science Quarterly, 29, 238-254.

[9] Staw, B.M. and Puffer, S.M. (1983) The Justification of Organizational Performance. Administrative Science Quarterly, 28, 582-600. http://dx.doi.org/10.2307/2393010

[10] Cho, C.H., Roberts, R.W. and Patten, D.M. (2010) The Language of US Corporate Environmental Disclosure. Accounting Organizations \& Society, 35, 431-443. http://dx.doi.org/10.1016/j.aos.2009.10.002

[11] Merkl-Davies, D.M. and Brennan, N.M. (2007) Discretionary Disclosure Strategies in Corporate Narratives: Incremental Information or Impression Management? Social Science Electronic Publishing, 26, 116-196.

[12] Elsbach, K.D. (1994) Managing Organizational Legitimacy in the California Cattle Industry: The Construction and Effectiveness of Verbal Accounts. Administrative Science Quarterly, 39, 57-88. http://dx.doi.org/10.2307/2393494

[13] Baginski, S.P., Hassell, J.M. and Hillison, W.A. (2000) Voluntary Causal Disclosures: Tendencies and Capital Market Reaction. Review of Quantitative Finance and Accounting, 15, 371-389. http://dx.doi.org/10.1023/A:1012002608615

[14] Barton, J. and Mercer, M. (2005) To Blame or Not to Blame: Analysts’ Reactions to External Explanations for Poor Financial Performance. Journal of Accounting and Economics, 39, 509-533. http://dx.doi.org/10.1016/j.jacceco.2005.04.006

[15] So, S. (2003) The Impact of Presentation Format and Individual Differences on the Communication of Information for Management Decision Making. Managerial Auditing Journal, 18, 59-67. http://dx.doi.org/10.1108/02686900310454273

[16] Le Seac'h, M. and Klotz, A. (1999) Corporate Translating: Handle with Care. Business \& Economic Review, 45, 12.

[17] Beattie, V. and Jones, M.J. (2001) A Six-Country Comparison of the Use of Graphs in Annual Reports. International Journal of Accounting, 36, 195-222. http://dx.doi.org/10.1016/S0020-7063(01)00094-2

[18] McKinstry, S. (1996) Designing the Annual Reports of Burton Plc from 1930 to 1994. Accounting, Organization and Society, 21, 66-70. http://dx.doi.org/10.1016/0361-3682(95)00016-3

[19] Grossman, S.J. (1981) The Role of Warranties and Private Disclosure about Product Quality. Journal of Law \& Economics, 24, 461-483. http://dx.doi.org/10.1086/466995

[20] Milgrom, P.R. (2015) Good News and Bad News: Representation Theorems and Applications. Bell Journal of Econom- 
ics, 12, 380-391. http://dx.doi.org/10.2307/3003562

[21] Verrecchia, R.E. (1983) Discretionary Disclosure. Journal of Accounting \& Economics, 5, 179-194. http://dx.doi.org/10.1016/0165-4101(83)90011-3

[22] Abrahamson, E. and Park, C. (1994) Concealment of Negative Organizational Outcomes: An Agency Theory Perspective. Academy of Management Journal, 37, 1302-1334. http://dx.doi.org/10.2307/256674

[23] Rutherford, B.A. (2003) Obfuscation, Textual Complexity and the Role of Regulated Narrative Accounting Disclosure in Corporate Governance. Journal of Management \& Governance, 7, 187-210. http://dx.doi.org/10.1023/A:1023647615279

[24] Schr, C.M. and Walther, B.R. (2011) Strategic Benchmarks in Earnings Announcements: The Selective Disclosure of Prior-Period Earnings Components. Accounting Review, 75, 151-177.

[25] Tedeschi, J.T. and Riess, M. (1981) Impression Management Theory and Social Psychological Research. Academic, New York.

[26] Jones, E.E., Pittman, T.S. and Jones, E.E. (1982) Toward a General Theory of Strategic Self-Presentation. In: Suls, J., Ed., Psychological Perspectives on the Self, Vol. 1, Erlbaum, Hillsdale, 231-262.

[27] Elsbach, K.D. and Sutton, R.I. (1992) Acquiring Organizational Legitimacy through Illegitimate Actions: A Marriage of Institutional and Impression Management Theories. Academy of Management Journal, 35, 699-738. http://dx.doi.org/10.2307/256313

[28] Schneider, A. and Samkin, G. (2010) Accountability, Narrative Reporting and Legitimation: The Case of a New Zealand Public Benefit Entity. Accounting Auditing \& Accountability Journal, 23, 256-289. http://dx.doi.org/10.1108/09513571011023219

[29] Linsley, P. and Kajuter, P. (2008) Restoring Reputation and Repairing Legitimacy: A Case Study of Impression Management in Response to a Major Risk Event at Allied Irish Banks Plc. International Journal of Financial Services Management, 3, 65-82. http://dx.doi.org/10.1504/IJFSM.2008.016699

[30] Clatworthy, M. and Jones, M.J. (2003) Financial Reporting of Good News and Bad News: Evidence from Accounting Narratives. Accounting \& Business Research, 33, 171-185. http://dx.doi.org/10.1080/00014788.2003.9729645

[31] Myria, W.A. and Caillouet, R.H. (1994) Legitimation Endeavors: Impression Management Strategies Used by an Organization in Crisis. Communication Monographs, 61, 44-62. http://dx.doi.org/10.1080/03637759409376322

[32] Healy, P.M. (1984) The Effects of Bonus Schemes on Accounting Decisions. Journal of Accounting \& Economics, 7, 85-107. http://dx.doi.org/10.1016/0165-4101(85)90029-1

[33] Watts, R.L. and Zimmerman, J.L. (1986) Positive Accounting Theory. Prentice Hall, Englewood Cliffs.

[34] Holthausen, R.W., Larcker, D.F. and Sloan, R.G. (1995) Annual Bonus Schemes and the Manipulation of Earnings. Journal of Accounting \& Economics, 19, 29-74. http://dx.doi.org/10.1016/0165-4101(94)00376-G

[35] Gaver, J.J. and Paterson, J.S. (1998) The Association between External Monitoring and Earnings Management in the Property-Casualty Insurance Industry. Journal of Accounting Research, 39, 269-282. http://dx.doi.org/10.1111/1475-679X.00012

[36] Weiner, B. (1971) Perceiving the Causes of Success and Failure. General Learning Press, New York.

[37] Krische, S.D. (2003) Investors’ Evaluations of Strategic Prior-Period Benchmark Disclosures in Earnings Announcements. Accounting Review, 80, 243-268. http://dx.doi.org/10.2308/accr.2005.80.1.243

[38] Schr, C.M. and Walther, B.R. (2011) Strategic Benchmarks in Earnings Announcements: The Selective Disclosure of Prior-Period Earnings Components. Accounting Review, 75, 151-177.

[39] Sun, M.L. (2005) An Empirical Study on the Company’s Annual Report of Self-Attribution Behavior. Economic Science, 86-93.

[40] Sun, M.L., Wang, H.C. and Ling, Z.J. (2007) An Extension Research on Attribution Bias in Corporations’ External Reports. Journal of Business and Economics, 52-56.

[41] Adelberg, A.H. (1979) Narrative Disclosures Contained in Financial Reports: Means of Communication or Manipulation? Accounting \& Business Research, 9, 179-190. http://dx.doi.org/10.1080/00014788.1979.9729157

[42] Subramanian, R., Insley, R.G. and Blackwell, R.D. (1993) Performance and Readability: A Comparison of Annual Reports of Profitable and Unprofitable Corporations. The Journal of Business Communication, 30, 49-61. http://dx.doi.org/10.1177/002194369303000103

[43] Mckinstry, S. (1996) Designing the Annual Reports of Burton Plc from 1930 to 1994. Accounting Organizations \& Society, 21, 89-111. http://dx.doi.org/10.1016/0361-3682(95)00016-3

[44] Beattie, V. and Jones, M.J. (2001) A Six-Country Comparison of the Use of Graphs in Annual Reports. International Journal of Accounting, 36, 195-222. http://dx.doi.org/10.1016/S0020-7063(01)00094-2 
[45] Steinbart, P.J. (1989) The Auditor’s Responsibility for the Accuracy of Graphs in Annual Reports: Some Evidence of the Need for Additional Guidance. Accounting Horizons, 3, 60-70.

[46] Sun, M.L. (2005) A Case Study of Self-serving Attribution in Annual Reports. International Accounting \& Finance, 40, 7-15.

[47] Cesario, J., Grant, H. and Higgins, E.T. (2004) Regulatory Fit and Persuasion: Transfer from “Feeling Right”. Journal of Personality and Social Psychology, 86, 388. http://dx.doi.org/10.1037/0022-3514.86.3.388

[48] Rämö, H. (2011) Visualizing the Phronetic Organization: The Case of Photographs in CSR Reports. Journal of Business Ethics, 104, 371-387. http://dx.doi.org/10.1007/s10551-011-0916-8

[49] Breitbarth, T., Harris, P. and Insch, A. (2010) Pictures at an Exhibition Revisited: Reflections on a Typology of Images Used in the Construction of Corporate Social Responsibility and Sustainability in Non-Financial Corporate Reporting. Journal of Public Affairs, 10, 238-257. http://dx.doi.org/10.1002/pa.344 